Number 6

\title{
GAMBARAN KADAR KREATININ SERUM PADA PENDERITA DIABETES MELLITUS TIPE 2 DI RUMAH SAKIT UMUM PUSAT SANGLAH DENPASAR
}

\author{
I Gusti Ayu Putu Widia Satia Padma ${ }^{1}$, Ida Ayu Made Sri Arjani ${ }^{2}$, I Nyoman Jirna ${ }^{3}$
}

\begin{abstract}
Background Diabetes mellitus (DM) is a metabolic disease which characterized by hyperglycemia due to abnormalities insulin secretions, insulin performance, or both of them. The condition of insulin resistance in DM type 2 causes chronic complications such as diabetic nephropathy. It has become the second leading cause of end-stage kidney disease, and one of the most common and demaging complication of diabetes. The level of creatinine in blood is one of the parameters used to assess renal function, as in the plasma concentration and excretion in the urine within 24 hours. Serum creatinine levels greater than the normal value suggests an impaired renal function.

Objective The purpose of this study was to determine serum creatinine levels in patients with DM type 2 in Sanglah General Hospital Denpasar.

Methods The method uses an analytical study with description, used accidental sampling methods, involving 30 patients with DM type 2. Blood samples were analyzed for creatinine levels and data are presented as table.

The reslts of this study showed that 60\% samples had high levels of serum creatinine, $30 \%$ samples had normal levels serum creatinine, and 10\% samples had low levels serum creatinine. From the result was concluded, most patients with DM type 2 in Sanglah Genaral Hospital have highly serum creatinine levels.
\end{abstract}

Keywords: creatinine serum, Diabetes Mellitus type 2

\section{Pendahuluan}

Diabetes mellitus (DM) merupakan suatu penyakit metabolik dengan karakteristik hiperglikemia yang terjadi karena kelainan sekresi insulin, kerja insulin, atau kedua-duanya. Diabetes mellitus menjadi masalah kesehatan yang utama dimasyarakat, karena penyakit ini jumlahnya meningkat dari tahun ke tahun.
Prevalensi diabetes di dunia terkait dengan usia meningkat dari 5,9\%-7,1\% pada kelompok usia 20-79 tahun. Berdasarkan penelitian yang dilakukan oleh World Health Organization (WHO) menunjukkan peningkatan tertinggi penderita diabetes terjadi di negara Asia Tenggara termasuk Indonesia. Data International Diabetes Federation (IDF) tahun 2014 menunjukkan 
9,1 juta penduduk Indonesia didiagnosis sebagai penyandang DM. Angka tersebut menjadikan Indonesia menempati peringkat ke-5 di dunia. Prevalensi diabetes di Indonesia mengalami peningkatan dari $1,1 \%$ pada tahun 2007 menjadi 2,7\% pada tahun 2013. Tahun 2013 prevalensi penderita diabetes di Bali berkisar 1,3\% dan persentase tertinggi yaitu $4,1 \%$ yang diderita oleh usia 55-64 tahun ${ }^{1}$.

Diabetes mellitus memiliki empat klasifikasi yang diklasifikasikan oleh PERKENI dan didasari oleh American Diabetes Association (ADA). Keempat klasifikasi dari diabetes ini sudah disahkan oleh World Health Organization (WHO) yaitu: DM tipe 1, tipe 2, tipe gestasional dan tipe khusus ${ }^{2}$. Diabetes mellitus tipe 2 merupakan tipe diabetes yang paling sering terjadi ${ }^{3}$. Diabetes mellitus tipe 2 merupakan suatu keadaan seseorang dengan kadar glukosa darah yang tinggi akibat dari gangguan sekresi insulin dan resistensi insulin,ini sering terjadi pada orang yang mengalami obesitas dan pertambahan usia ${ }^{4}$.

Diabetes mellitus dapat memberikan berbagai komplikasi salah satunya komplikasi kronik yang dapat menyerang berbagai organ seperti mata, ginjal, saraf dan pembuluh darah. Penyakit yang disebabkan karena komplikasi kronik mikrovaskuler yang terjadi pada pasien DM salah satunya adalah nefropati diabetika ${ }^{6}$ Nefropati diabetika merupakan suatu keadaan dimana ginjal mengalami penurunan fungsi dan terjadinya kerusakanpada selaput penyaring darah yang disebabkan oleh kadar gula darah yang tinggi. Nefropati diabetika dijumpai pada $35-45 \%$ pasien DMyang dapat menyebabkan terjadinya gagal ginjal terminal dan menjadi penyebab utama kematian tertinggi pada pasien $\mathrm{DM}^{5}$.

Pemeriksaan kreatinin serum merupakan pemeriksaan yang spesifik dan salah satu indikator untuk mengetahui kerusakan fungsi ginjal karena, kadar kreatinin serum tidak dipengaruhi oleh konsumsi protein, serta konsentrasi dalam plasma dan ekskresinya di urin dalam 24 jam relatif konstan ${ }^{6}$. Kreatinin merupakan hasil metabolisme endogen dari otot skeletal yang diekskresikan melalui filtrasi glomerulus yang akan dibuang melalui urine dan tidak direabsorbsi atau disekresikan oleh tubulus ginjal. Tinggi rendahnya kadar kreatinin dalam darah digunakan sebagai indikator penting dalam menentukan apakah seorang mengalami gangguan fungsi ginjal ${ }^{7}$ sehingga, pemeriksaan kreatinin serum dapat berfungsi sebagai indikator perjalanan 
penyakit DM tipe 2 yang berpotensi mengalami gagal ginjal dan sebagai kontrol fungsi ginjal pada penderita DM Tipe 2 yang sudah mengalami komplikasi gagal ginjal $^{8}$. Tujuan penelitian ini adalah untuk mengetahui gambaran kadar kreatinin serum pada penderitaDM tipe 2 di Rumah Sakit Umum Pusat Sanglah Denpasar.

\section{Metode}

Penelitian ini merupakan penelitian survei deskriptif. Pengambilan sampel dilakukan di Poliklinik Diabetic Centre RSUP Sanglah Denpasar, dan pemeriksaan sampel penelitian dilakukan di Laboratorium Patologi Klinik RSUP Sanglah Denpasar pada bulan Maret sampai dengan bulan Juni 2017. Populasi pada penelitian ini adalah seluruh penderita diabetes mellitus tipe $2 \mathrm{di}$ Poliklinik Diabetic Centre RSUP Sanglah Denpasar dengan besar sampel adalah 30 sampel. Teknik sampling yang digunakan Nonprobability Sampling dan penentuan sampel dengan Accidental Sampling ${ }^{9}$. Teknik pengumpulan data dalam penelitian ini dilakukan dengan pengukuran kadar kreatinin serum dan melihat data rekam medis pasien. Data yang diperoleh elanjutnya dikumpulkan, dikelompokkan berdasarkan karakteristik penderita, diolah, dan disajikan dalam bentuk tabel serta diberi narasi.

\section{Hasil dan Pembahasan}

\section{Hasil}

\section{Karakteristik subjek penelitian}

Tabel 1

Karakteriktik Penderita DM Tipe 2 Berdasarkan Kelompok Usia

\begin{tabular}{cccc}
\hline No. & Kelompok Usia (Th) & Jumlah & $\%$ \\
\hline 1 & $31-40$ & 1 & 3,3 \\
2 & $41-50$ & 4 & 13,3 \\
3 & $51-60$ & 9 & 30 \\
4 & $61-70$ & 11 & 36,7 \\
5 & $71-80$ & 5 & 16,7 \\
\hline & Total & 30 & 100 \\
\hline
\end{tabular}

Berdasarkan pada Tabel 1, dari 30 orang responden penderita DM Tipe 2 di RSUP Sanglah yang diteliti menunjukkan pada kelompok usia 61-70 tahun memiliki jumlah paling tinggi yaitu 11 orang $(36,7 \%)$.

a. Karakteristik Penderita DM Tipe 2 berdasarkan jenis kelamin 
Tabel 2

Karakteriktik Penderita DM Tipe 2 Berdasarkan Jenis Kelamin

\begin{tabular}{cccc}
\hline No. & Jenis Kelamin & Jumlah & $\%$ \\
\hline 1 & Laki-laki & 14 & 46,7 \\
2 & Perempuan & 16 & 53,3 \\
\hline & Total & 30 & 100 \\
\hline
\end{tabular}

Berdasarkan pada Tabel 2, kelamin perempuan sebanyak 16 orang menunjukkan bahwa penderita DM Tipe 2 di $\quad(53,3 \%)$.

RSUP Sanglah yang menjadi sampel b. Karakteristik penderita DM Tipe 2 penelitian didominasi oleh penderita berjenis berdasarkan lamanya menderita diabetes mellitus

Tabel 3

Karakteriktik Penderita DM Tipe 2 Berdasarkan Lama Menderita Diabetes Mellitus

\begin{tabular}{cccc}
\hline No. & Lama Menderita (Th) & Jumlah & $\%$ \\
\hline 1 & $1-5$ & 11 & 36,7 \\
2 & $6-10$ & 15 & 50 \\
3 & $11-15$ & 3 & 10 \\
4 & $16-20$ & 1 & 3,3 \\
\hline & Total & 30 & 100 \\
\hline
\end{tabular}

Berdasarkan pada Tabel 3 menunjukkan bahwa penderita DM Tipe 2 yang menjadi sampel penelitian lebih didominasi oleh penderita dengan kelompok lama menderita 6-10 tahun yaitu 15 orang $(50 \%)$.

c. Karakteristik Penderita DM Tipe 2 berdasarkan komplikasi yang dialami

Tabel 4

Karakteriktik Penderita DM Tipe 2 Berdasarkan Komplikasi yang Dialami

\begin{tabular}{cccc}
\hline No. & Komplikasi & Jumlah & $\%$ \\
\hline 1 & CKD dan Hipertensi & 9 & 30 \\
2 & CKD & 7 & 23,3 \\
3 & Hipertensi & 5 & 16,7
\end{tabular}

Meditory | ISSN Online : 2549-1520, ISSN Cetak : 2338 - 1159, Vol. 5, No. 2, Desember 2017 HIm. 107 - 117, http://ejournal.poltekkes-denpasar.ac.id 


\begin{tabular}{cccc}
4 & Lain-Lain & 5 & 16,7 \\
5 & Tidak Ada Komplikasi & 4 & 13,3 \\
\hline Total & 30 & 100 \\
\hline
\end{tabular}

Berdasarkan pada Tabel 4 menunjukkan bahwa pasien DM Tipe 2 di RSUP Sanglah yang menjadi sampel penelitian didominasi oleh pasien yang mengalami komplikasi CKD dan hipertensi yaitu sebanyak 9 orang $(30 \%)$.

\section{Hasil pengamatan terhadap subjek penelitian berdasarkan variabel penelitian}

a. Distribusi kadar kreatinin serum pada penderita DM Tipe 2 di RSUP Sanglah Denpasar

Berdasarkan hasil penelitian terhadap 30 penderita DM Tipe 2, diperoleh sebanyak 9 orang $(30 \%)$ memiliki kadar kreatinin yang normal, 18 orang $(60 \%)$ memiliki kadar kreatinin tinggi dan 3 orang (10\%) dengan kadar kreatinin rendah, dengan nilai rata-rata kreatinin pada 30 sampel yaitu $1,29 \mathrm{mg} / \mathrm{dl}$, nilai maksimum sebesar 3,03 mg/dl, nilai minimum sebesar $0,31 \mathrm{mg} / \mathrm{dl}$ dan standar deviasi sebesar 0,61 $\mathrm{mg} / \mathrm{dl}$. Nilai normal kreatinin serum untuk laki-laki yaitu 0,7-1,2 $\mathrm{mg} / \mathrm{dl}$, sedangkan untuk perempuan $0,5-0,9 \mathrm{mg} / \mathrm{dl}$.

b. Distribusi kadar kreatinin serum pada penderita DM Tipe 2 di RSUP Sanglah Denpasar berdasarkan kelompok usia

Tabel 5

Kadar Kreatinin Serum Pada Penderita DM Tipe 2 Berdasarkan Kelompok Usia Usia (Th) Kadar Kreatinin Serum (mg/dl) Jumlah

\begin{tabular}{ccccccccc} 
& \multicolumn{2}{l}{ Normal } & \multicolumn{7}{l}{ Tinggi } & \multicolumn{2}{c}{ Rendah } \\
\cline { 2 - 7 } & $\mathrm{N}$ & $\%$ & $\mathrm{~N}$ & $\%$ & $\mathrm{~N}$ & $\%$ & $\Sigma$ & $\%$ \\
\hline $31-40$ & 0 & 0 & 0 & 0 & 1 & 33,3 & 1 & 3,3 \\
$41-50$ & 1 & 11,1 & 3 & 16,7 & 0 & 0 & 4 & 13,3 \\
$51-60$ & 5 & 55,6 & 2 & 11,1 & 2 & 66,7 & 9 & 30 \\
$61-70$ & 2 & 22,2 & 9 & 50 & 0 & 0 & 11 & 36,7 \\
$71-80$ & 1 & 11,1 & 4 & 22,2 & 0 & 0 & 5 & 16,7 \\
\hline Total & 9 & 100 & 18 & 100 & 3 & 100 & 30 & 100 \\
\hline
\end{tabular}

Berdasarkan pada Tabel 5, bahwa penelitian yang telah dilakukan pada 30 penderita DM Tipe 2 di RSUP Sanglah yang berusia 31-80 tahun diperoleh tiga kategori hasil pemeriksaan kadar kreatinin serum yaitu normal, tinggi dan rendah. Diperoleh 18 orang memiliki kadar kreatinin tinggi yang didominasi oleh kelompok usia 61-70 tahun yaitu 9 orang $(50 \%)$. 
c. Distribusi kadar kreatinin serum pada Denpasar berdasarkan jenis kelamin penderita DM Tipe 2 di RSUP Sanglah

Tabel 6

Kadar Kreatinin Serum Pada Penderita DM Tipe 2 Berdasarkan Jenis Kelamin

\begin{tabular}{cccccccccc}
\hline \multirow{2}{*}{ Jenis Kelamin } & \multicolumn{4}{c}{ Kadar Kreatinin Serum (mg/dl) } & \multicolumn{2}{c}{ Jumlah } \\
\cline { 2 - 8 } & \multicolumn{3}{c}{ Normal } & \multicolumn{2}{c}{ Tinggi } & \multicolumn{2}{c}{ Rendah } & & \\
\hline & $\mathrm{N}$ & $\%$ & $\mathrm{~N}$ & $\%$ & $\mathrm{n}$ & $\%$ & $\Sigma$ & $\%$ \\
\hline Laki-Laki & 3 & 33,3 & 10 & 55,6 & 1 & 33,3 & 14 & 46,7 \\
Perempuan & 6 & 66,7 & 8 & 44,4 & 2 & 66,7 & 16 & 53,3 \\
\hline Total & 9 & 100 & 18 & 100 & 3 & 100 & 30 & 100 \\
\hline
\end{tabular}

Berdasarkan pada Tabel 6 diperoleh

$(44,4 \%)$ dengan jenis kelamin perempuan 18 orang penderita DM Tipe 2 memiliki memiliki kadar kreatinin serum yang tinggi kadar kreatinin serum tinggi. Hasil tersebut (> 0,5-0,9 mg/dl.) didominasi oleh penderita dengan jenis kelamin laki-laki yaitu 10 orang $(55,6 \%)$ memiliki kadar kreatinin serum yang tinggi (> $0,7-1,2 \mathrm{mg} / \mathrm{dl})$, sementara 8 orang

Tabel 7

Kadar Kreatinin Serum Pada Penderita DM Tipe 2 Berdasarkan Lama Menderita

\begin{tabular}{ccccccccc}
\hline \multirow{2}{*}{$\begin{array}{c}\text { Lama Menderita } \\
\text { (Th) }\end{array}$} & \multicolumn{4}{c}{ Kadar Kreatinin Serum (mg/dl) } & \multicolumn{2}{c}{ Jumlah } \\
\cline { 2 - 7 } & \multicolumn{2}{c}{ Normal } & \multicolumn{2}{c}{ Tinggi } & \multicolumn{2}{c}{ Rendah } & & \\
\hline $1-5$ & 6 & 6 & $\mathrm{~N}$ & $\%$ & $\mathrm{~N}$ & $\%$ & $\Sigma$ & $\%$ \\
\hline $6-10$ & 2 & 22,2 & 13 & 72,2 & 0 & 0 & 15 & 56,7 \\
$11-15$ & 1 & 11,1 & 2 & 11,1 & 0 & 0 & 3 & 10 \\
$16-20$ & 0 & 0 & 1 & 5,6 & 0 & 0 & 1 & 3,3 \\
\hline Total & 9 & 100 & 18 & 100 & 3 & 100 & 30 & 100 \\
\hline
\end{tabular}

Berdasarkan pada Tabel 7 dari 18 orang penderita DM Tipe 2 yang memiliki kadar

Meditory | ISSN Online : 2549-1520, ISSN Cetak : 2338-1159, Vol. 5, No. 2, Desember 2017 
kreatinin serum tinggi diperoleh hasil yang mendominasi sebanyak 13 orang $(72,2 \%)$ dari kelompok lama mederita 6-10 tahun. e. Distribusi kadar kreatinin serum pada penderita DM Tipe 2 di RSUP Sanglah Denpasar berdasarkan komplikasi yang dialami.

Tabel 8

Kadar Kreatinin Serum Pada Penderita DM Tipe 2 Berdasarkan Komplikasi yang Dialami

\begin{tabular}{|c|c|c|c|c|c|c|c|c|}
\hline \multirow{3}{*}{ Komplikasi } & \multicolumn{6}{|c|}{ Kadar Kreatinin Serum (mg/dl) } & \multirow{2}{*}{\multicolumn{2}{|c|}{ Jumlah }} \\
\hline & \multicolumn{2}{|c|}{ Normal } & \multicolumn{2}{|c|}{ Tinggi } & \multicolumn{2}{|c|}{ Rendah } & & \\
\hline & $\mathrm{N}$ & $\%$ & $\mathrm{~N}$ & $\%$ & $\mathrm{~N}$ & $\%$ & $\Sigma$ & $\%$ \\
\hline $\begin{array}{l}\text { CKD dan } \\
\text { Hipertensi }\end{array}$ & 1 & 11,1 & 8 & 44,4 & 0 & 0 & 9 & 30 \\
\hline CKD & 1 & 11,1 & 6 & 33,3 & 0 & 0 & 7 & 23,3 \\
\hline Hipertensi & 3 & 33,3 & 2 & 11,1 & 0 & 0 & 5 & 16,7 \\
\hline $\begin{array}{l}\text { Selain CKD dan } \\
\text { Hipertensi }\end{array}$ & 2 & 22,2 & 1 & 5,6 & 2 & 66,7 & 5 & 16,7 \\
\hline $\begin{array}{l}\text { Tidak Ada } \\
\text { Komplikasi }\end{array}$ & 2 & 22,2 & 1 & 5,6 & 1 & 33,3 & 4 & 13,3 \\
\hline Total & 9 & 100 & 18 & 100 & 3 & 100 & 30 & 100 \\
\hline
\end{tabular}

Berdasarkan pada Tabel 8 diperoleh hasil penelitian yang dilakukan pada 30 penderita DM Tipe 2 dengan karakteristik komplikasi yang dialami didapatkan 18 orang memiliki kadar kreatinin serum tinggi, dari jumlah tersebut kadar kreatinin serum dengan kategori tinggi lebih didominasi oleh penderita dengan komplikasi CKD dan Hipertensi yaitu 8 orang $(44,4 \%)$.

\section{A. Pembahasan}

1. Kadar kreatinin serum pada penderita DM Tipe 2
Penelitian yang dilakukan di RSUP Sanglah Denpasar pada 30 penderita DM Tipe 2 diperoleh kadar kreatinin yang dikelompokkan menjadi 3 kategori yaitu tinggi, rendah dan normal. Hasil kreatinin dikatakan tinggi atau rendah jika nilainya melebihi atau kurang dari batas normal $(0,5-$ $0,9 \mathrm{mg} / \mathrm{dl}$ pada perempuan dan 0,7-1,2 $\mathrm{mg} / \mathrm{dl}$ pada laki-laki). Berdasarkan hasil penelitian diperoleh sebanyak $60 \%$ memiliki kadar kreatinin yang tinggi, 10\% memiliki 
kadar kreatinin yang rendah, dan 30\% memiliki kadar kreatinin yang normal.

a. Kadar kreatinin serum pada penderita DM Tipe 2 berdasarkan kelompok usia Hasil penelitian diperoleh kadar kreatinin serum yang tinggi didominasi pada kelompok usia 61-70 tahun yaitu 50\%. Hal ini sesuai dengan teori bahwa faktor usia dapat mempengaruhi kadar kreatinin dimana kadar kreatinin pada lansia jauh lebih tinggi daripada orang $\operatorname{muda}^{10}$. Kadar kreatinin yang tinggi menandakan sudah mulai menurunnya fungsi ginjal yang akan mengarah ke gagal ginjal disamping itu juga kadar kreatinin yang tinggi disebabkan karena penderita DM Tipe 2 sudah mengalami komplikasi gagal ginjal. Seiring bertambahnya usia seseorang juga akan diikuti oleh penurunan pada fungsi ginjalnya. Hal tersebut terjadi karena pada usia lebih dari 40 tahun akan mengalami proses hilangnya beberapa nefron, menyebabkan filtrasi kreatinin tidak sempurna sehingga kadar kreatinin dalam darah meningkat ${ }^{11}$. Semakin meningkatnya usia ditambah dengan penyakit kronis seperti DM, ginjal cenderung akan menjadi rusak akibat dari kadar gula darah yang tinggi dan fungsi ginjal tidak dapat dipulihkan kembali sehingga banyak penderita DM mengalami komplikasi gagal ginjal $^{12}$.

b. Kadar kreatinin serum pada penderita DM Tipe 2 berdasarkan jenis kelamin

Berdasarkan hasil penelitian diperoleh kadar kreatinin tinggi lebih banyak dijumpai pada penderita DM Tipe 2 berjenis kelamin laki-laki yaitu $55,6 \%$ daripada perempuan. Hal ini dikarenakan kreatinin dipengaruhi oleh perubahan massa otot, aktifitas fisik yang berlebihan pada laki-laki sehingga menyebabkan kadar kreatinin lebih tinggi daripada wanita ${ }^{10}$.

Perempuan biasanya memiliki kadar kreatinin rendah dibandingkan laki-laki, karena perempuan biasanya memiliki massa otot yang lebih kecil. Kreatinin merupakan hasil sisa metabolisme protein otot, jumlah kreatin per unit massa otot skelet konsisten dan tingkat kerusakan kreatin juga konsisten. Dengan demikian, konsentrasi kreatinin plasma sangat stabil dan merupakan cerminan langsung dari massa otot skeletal. Hal ini sesuai pada penelitian yang dilakukan yaitu diperoleh 2 orang $(66,7 \%)$ perempuan memiliki nilai kreatinin yang rendah dan 1 orang $(33,3 \%)$ laki-laki ${ }^{13}$.

Penelitian tentang Study of Renal Function Parameters in Type 2 Diabetic Patients, diperoleh hasil penelitian 
menunjukkan kadar kreatinin lebih tinggi pada laki-laki yaitu berjumlah 25 orang dari 40 responden. Shresta menyatakan hal ini terjadi karena perbedaan massa otot laki-laki dan perempuan sehingga mempengaruhi dari kadar kreatinin ${ }^{13}$.

c. Kadar kreatinin serum penderita DM Tipe 2 berdasarkan lama menderita

Berdasarkan hasil penelitian yang telah dilakukan, kadar kreatinin serum pada penderita DM Tipe 2 di RSUP Sanglah Denpasar berdasarkan lama menderita didapatkan hasil bahwa kadar kreatinin yang tinggi lebih banyak dijumpai pada kelompok lama menderita DM Tipe 2 selama 6-10 tahun yaitu $72,2 \%$. Beberapa penelitian menunjukkan penderita DM tipe-2 yang baru dikenal umumnya telah menderita DM selama lebih kurang 4-7 tahun sebelum diagnosis ditegakkan. Pada saat diagnosis ditegakkan, 25\% mengalami retinopati, 9\% neuropati dan $8 \%$ nefropati ${ }^{10}$. Semakin lama DM maka semakin tinggi risiko terjadinya gagal ginjal terminal dimana komplikasi gagal ginjal terminal ini sering kali didapatkan pada penderita DM dalam kurun waktu >5 tahun yaitu sebesar $52,94 \%{ }^{13}$. Pada responden yang mengalami Nefropati diabetika atau gagal ginjal, onset DM yang paling sering menimbulkan komplikasi ginjal adalah 5-10 tahun. Diabetes yang lama menyebabkan perubahan pada pembuluh darah kecil yang dapat menyebabkan kerusakan ginjal dimana kerusakan ginjal tersebut dapat menyebabkan kegagalan ginjal yang berat. Kerusakan ginjal dapat dimulai sejak tahun pertama setelah terdiagnosis menderita DM tipe I dan dapat ditemukan pada saat terdiagnosis DM tipe II. Namun diperlukan waktu sekitar 5 - 10 tahun untuk menjadi masalah kerusakan ginjal yang bermakna ${ }^{5}$.

Pasien yang kadar gulanya tidak terkontrol memiliki kadar kreatinin yang masih dalam batas normal yaitu sebanyak 1 orang $(12,5 \%)$. Hal ini disebabkan karena belum lamanya pasien menderita diabetes mellitus sehingga komplikasi diabetes belum terjadi. Selain itu, kadar kreatinin bukan hanya dipengaruhi oleh kadar gula darah, tetapi bisa pula dipengeruhi oleh diet seseorang. Hal ini sejalan dengan penelitian yang dilakukan pada penderita DM Tipe 2 di RSUP Sanglah Denpasar, diperoleh hasil kreatinin yang rendah yaitu 3 orang (100\%) pada kelompok lama menderita 1-5 tahun ${ }^{11}$.

d. Kadar kreatinin serum pada penderita DM Tipe 2 berdasarkan komplikasi yang dialami 
Hasil penelitian yang dilakukan di RSUP Sanglah Denpasar dari 30 orang responden diperoleh berbagai komplikasi yang dapat dialami oleh penderita DM Tipe 2 sehingga menyebabkan nilai kreatinin tinggi, namun komplikasi yang paling dominan adalah CKD (gagal ginjal) dan Hipertensi, yaitu sebanyak $44,4 \%$. Hal ini dikarenakan penderita DM yang mengalami komplikasi seperti gagal ginjal memang menyebabkan kadar kreatinin meningkat dan kadar kreatinin dapat menjadi kontrol fungsi ginjal bagi penderita DM yang telah mengalami komplikasi CKD. Dalam penelitian yang dilakukan oleh Saranya pada tahun 2015 tentang Evaluation of Relationship Between Renal Abnormalities and Dyslipidemia on Type 2 Diabetes mellitus mengatakan bahwa hiperglikemia merupakan salah satu penyebab utama kerusakan ginjal yang progresif $^{13}$.

Nefropati diabetika merupakan salah satu komplikasi gangguan pada fungsi ginjal yang dapat menyebabkan gagal ginjal pada penderita DM. Seseorang penderita diabetes yang sudah mengalami komplikasi gagal ginjal disertai dengan peningkatan tekanan darah akan mengakibatkan menurunnya filtrasi glomerulus dan akhirnya gagal ginjal tahap akhir. Gagal ginjal tersebut akan mengakibatkan peningkatan kadar kreatinin, hal ini dikarenakan kreatinin tidak akan mampu lagi difiltrasi dan disekresikan secara sempurna oleh ginjal ${ }^{10}$. Kadar glukosa darah yang tinggi dalam tubuh secara perlahan mampu merusak selaput filtrasi, karena glukosa akan bereaksi dengan protein sehingga mampu mengubah struktur dan fungsi sel termasuk membran basal glomerulus. Lapisan penghalang protein yang rusak akan mengakibatkan terjadinya kebocoran protein ke urin (albuminuria), hal ini dapat menyebabkan terjadinya gangguan fungsi ginjal ${ }^{1}$.

\section{Simpulan}

Berdasarkan karakteristik, kadar kreatinin serum yang tinggi lebih didominasi pada kelompok usia 61-70 tahun 50\%. Jenis kelamin lebih banyak dijumpai pada lakilaki 55,6\%, dan kadar kreatinin serum yang rendah didominasi pada perempuan $66,7 \%$. Penderita DM tipe 2 diperoleh hasil yang tinggi pada penderita dengan lama menderita 6-10 tahun 72,2\%, dan hasil yang rendah pada penderita dengan lama menderita 1-5 tahun $100 \%$. Berdasarkan komplikasi yang dialami oleh penderita DM Tipe 2, kadar kreatinin yang tinggi dijumpai pada penderita yang mengalami CKD dan hipertensi 44,4\%, kadar yang rendah 
dijumpai pada penderita yang mengalami komplikasi selain CKD dan hipertensi $66,7 \%$.

\section{Saran}

Diharapkan kepada pasien untuk mematuhi diet yang diberikan oleh pihak rumah sakit ataupun dokter untuk menjaga kadar gula darah penderita DM Tipe 2 tetap optimal, agar komplikasi dapat dicegah dan tidak memperburuk keadaan apabila sudah mengalami komplikasi.

\section{DAFTAR PUSTAKA}

1. Hasdianah, H.R. 2012. Mengenal Diabetes Mellitus Pada Orang Dewasa dan Anak-Anak dengan Solusi Herbal. Yogyakarta: Nuha Medika

2. Riskesdas 2013. Badan Penelitian dan Pengembangan Kesehatan Kementerian RI Tahun 2013

3. Price, S.A., dan L.M. Wilson. 2012. Patofisiologi Konsep Klinis Proses-Proses Penyakit Edisi 6 Vol 2. Jakarta: EGC

4. Mahara, N.D. 2016. Hubungan Kadar Kreatinin Serum Dengan Kadar Gula Darah Puasa Pada Pasien Diabetes Melitus Tipe 2 Di Rsud Dr. Sayidiman Kabupaten Magetan.http://eprints.ums.ac.id/42181/1/Naska h\%20Publikasi.pdf. diakses tanggal 22 November 2016.

5. Pratama, A.A.Y. 2013. Korelasi Lama Diabetes Melitus Terhadap Kejadian Nefropati Diabetika: Studi Kasus di Rumah Sakit Dokter Kariadi Semarang. Jurnal Media Medika Muda 1:1-7

6. Smeltzer, S.C. 2014. Keperawatan MedikalBedah Brunner \& Suddarth Edisi 12. Jakarta: EGC

7. Alfonso, A A., A.E. Mongan, dan M.F. Memah. 2016. Gambaran Kadar Kreatinin Serum Pada Pasien Penyakit Ginjal KronikStadium 5 Non Dialisis. Jurnal e-Biomedik 4(1): 178-183

8. Rehman G., S.A. Khan, dan Hamayun M. 2008. Studies on diabetic nephropathy and secondary diseases in type 2 diabetes. Int. J. Diab. Dev. Ctries 25: 25-29.

9. Notoatmodjo, S. 2012. Metodologi Penelitian Kesehatan, Edisi Revisi Cetakan Kedua. Jakarta: Rineka Cipta.

10. Suryawan, D.G.A. 2016. Gambaran Ureum dan Kreatinin Serum Pada Pasien Gagal Ginjal Kronik Sebelum Menjalani Jadwal Hemodialisa di RSUD Sanjiwani Gianyar. Meditory 4(2): 145-153.

11. Dabla, P.K. 2010. Renal Function in Diabetic Nephropathy. World Journal of Diabetes 1(2): 48-56.

12. Dabla, P.K. 2010. Renal Function in Diabetic Nephropathy. World Journal of Diabetes 1(2): 48-56.

13. Sahid, QAU. 2012. Hubungan Lama Diabetes Melitus Dengan Terjadinya Gagal Ginjal Terminal Di Rumah Sakit Dr. Moewardi Surakarta [skripsi]. Fakultas Kedokteran Universitas Muhammadiyah Surakarta. 